\title{
STRUKTUR DAN KOMPOSISI HUTAN PAMAH BEKAS TEBANGAN ILEGAL DI KELOMPOK HUTAN SEI LEPAN, SEI SERDANG, TAMAN NASIONAL GUNUNG LEUSER, SUMATERA UTARA \\ (Structure and Species Composition of Lowland Disturbed Forest at Lepan River Forest Complex, Sei Serdang, Gunung Leuser National Park, North Sumatra)*
}

\author{
Oleh/By: \\ Ismayadi Samsoedin $^{1}$ dan/and N.M. Heriyanto ${ }^{2}$ \\ ${ }^{1}$ Pusat Litbang Perubahan Iklim dan Kebijakan \\ Jl. Gunung Batu No. 5 Po Box 272 Telp. (0251) 8633944; Fax (0251) 8634924 Bogor \\ ${ }^{2}$ Pusat Litbang Konservasi dan Rehabilitasi \\ Jl. Gunung Batu No. 5 Po Box 165; Telp. 0251-8633234, 7520067; Fax 0251-8638111 Bogor \\ *Diterima : 16 Januari 2009; Disetujui : 1 Oktober 2010
}

\begin{abstract}
This study was aimed to observe stand structure and species composition of trees (diameter at breast height of $\geq 10 \mathrm{~cm}$ ) as well as saplings in low land disturbed forest of Lepan River Forest Complex, Sei Serdang, Gunung Leuser National Park, North Sumatra. Sampling was done in a one-hectare plot located at the elevation of $237.6 \mathrm{~m}$ above sea level. The result of observation recorded 110 species and 34 families with the density of 687 trees/ha and total basal area of $24.52 \mathrm{~m}^{2} / \mathrm{ha}$. The dominant families were Euphorbiaceae, Dipterocarpaceae, and Myrtaceae while the dominant species were Macaranga hoseii King ex Hook.f., Shorea sp., and Shorea multiflora (Burk.) Symington. The density of saplings and seedlings were 12,800 trees/ha and 29,700 trees/ha respectively. The total volume of trees with diameter of $\geq 10 \mathrm{~cm}$ was $358.11 \mathrm{~m}^{3} / \mathrm{ha}$. Tree species found in all vegetation stages (tree, sapling, and seedling) were Archidendron sp. which was dominant in sapling and seedling stages (Important Value Index (IVI) 37.27\% and $35.0 \%$ respectively), and Shorea sp. which was dominant in tree stage (IVI 19.88\%). The dominant tree species not found in seedling and tree stages included Vatica sp. (IIV 4.19\%), Knema curtisii (King) Warb. (IVI 3.56\%), and Heritiera sumatrana (IVI 2.01\%). The dominant seedling species not found in tree and sapling stages were Xanthophyllum sp. (IVI 2.85\%), Rinorea sp. (IVI 2.10\%), Horsfieldia sp., and Dysoxylum sp. (IVI 1.76\% each).
\end{abstract}

Keywords: Structure, composition, regeneration, lowland disturbed forest

\begin{abstract}
ABSTRAK
Penelitian ini bertujuan untuk mengetahui struktur tegakan dan komposisi jenis pohon (diameter setinggi dada $\geq 10 \mathrm{~cm}$ ), pancang, dan semai di hutan pamah terganggu di kelompok hutan Sei Lepan, Sei Serdang, Taman Nasional Gunung Leuser, Sumatera Utara. Sampling dilakukan pada petak pengamatan berukuran satu ha pada ketinggian 237,6 m dari permukaan laut. Berdasarkan hasil penelitian, tercatat 110 jenis pohon berdiameter $\geq 10 \mathrm{~cm}$ dan berjumlah 687 pohon dengan luas bidang dasar $24,52 \mathrm{~m}^{2} / \mathrm{ha}$. Jenis tersebut tergolong dalam 34 suku, dimana suku yang mempunyai jenis terbanyak adalah Euphorbiaceae, Dipterocarpaceae, dan Myrtaceae. Jenis-jenis yang dominan berturut-turut adalah Macaranga hoseii King ex Hook.f., Shorea sp., dan Shorea multiflora (Burk) Symington. Kerapatan pancang dan semai sebesar 12.800 batang/ha dan 29.700 batang/ha. Potensi pohon berdiameter $\geq 10 \mathrm{~cm}$ di lokasi penelitian sebesar 358,11 $\mathrm{m}^{3} / \mathrm{ha}$. Jenis pohon yang mendominasi regenerasi lengkap (tingkat pohon, pancang dan semai), yaitu jenis Archidendron sp. dengan INP pada tingkat semai 37,27\% dan pada tingkat pancang 35\%), dan jenis Shorea sp. yang dominan pada tingkat pohon dengan INP 19,88\%. Pohon tanpa regenerasi, baik di tingkat pancang maupun semai didominasi oleh jenis Shorea inappendiculata Burck. (INP 11,91\%), Melicope glabra (Blume) T.G.Hortley. (INP 9,91\%), dan jenis Durio excelsus Griff. (INP 9,48\%). Pancang tanpa regenerasi di tingkat semai didominasi berturut-turut oleh Vatica sp. (INP 4,19\%), Knema curtisii (King) Warb. (INP 3,56\%), dan Heritiera sumatrana (INP 2,01\%), sedangkan tingkat semai didominasi oleh Xanthophyllum sp. (INP 2,85\%), Rinorea sp. (INP 2,10\%), serta Horsfieldia sp. dan Dysoxylum sp. (INP masing-masing sebesar 1,76\%).
\end{abstract}

Kata kunci: Struktur, komposisi, regenerasi, hutan pamah terganggu 


\section{PENDAHULUAN}

Taman Nasional Gunung Leuser (TNGL) dengan luas sekitar satu juta hektar memiliki 350 jenis burung dan lebih dari 4.000 jenis flora (Wiratno et al., 2004). Selanjutnya dinyatakan jenis fauna penting yang menjadi sorotan internasional di TNGL adalah orangutan (Pongo abelii Lesson, 1827), harimau sumatera (Panthera tigris sumatrae Pocock, 1929), badak sumatera (Dicerorhinus sumatrensis G. Fischer, 1814), dan owa (Hylobates laar Linnaeus, 1771). Oleh karena itu, sejak tahun 1934 kawasan ini telah ditetapkan sebagai suaka alam dan menjadi taman nasional pada tahun 1980, kemudian pada tahun 1981 UNESCO menetapkannya sebagai cagar biosfer.

Dalam kondisi sekarang, berbagai program perlindungan dan pemberdayaan masyarakat untuk meningkatkan partisipasi dalam perlindungan TNGL dan peningkatan sosial ekonomi masyarakat telah dilaksanakan. Termasuk kegiatan mengatasi perambahan hutan (illegal logging) dan pemulihan dampaknya serta pemulihan habitat yang telah terinvasi oleh masyarakat.

Di antara kegiatan rehabilitasi habitat, restorasi ekosistem menjadi kegiatan penting. Pada tahun 2004 Menteri Kehutanan mengeluarkan keputusan No. SK. 159/Menhut-II/2004 tentang restorasi ekosistem di hutan produksi, sudah mengisyaratkan kegiatan restorasi untuk membangun kembali fungsi hutan. Pelaksana restorasi mengemukakan pentingnya restorasi ini berdasarkan tingginya keanekaragaman hayati dan populasi spesies kunci di kawasan hutan yang direstorasi. Contoh program restorasi telah dilakukan oleh Restorasi Ekosistem Indonesia (REKI) di Jambi, dimana terdapat 269 jenis burung, 70 jenis di antaranya terancam punah. Kawasan ini juga merupakan habitat harimau sumatera (Dicerorhinus sumatrensis Pocock, 1929), gajah, dan tapir (REKI, 2005).
Berdasarkan penelitian Priatna et al. (2006), di kawasan hutan bekas tebang pilih berumur 18 tahun di kawasan sekunder TNGL menunjukkan perubahan jenis yang tidak signifikan, yaitu dari 127 jenis menjadi 133 jenis yang didominasi oleh Euphorbiaceae dan Dipterocarpaceae. Peningkatan populasi terjadi pada jumlah Baccaurea kunstleri King., Endospermum diadenum Airy Shaw, Mallotus penangensis Muell Arg., Sapium baccatum Roxb., dan Macaranga diepenhorstii Muell Arg.

Penelitian ini bertujuan untuk mendapatkan informasi tentang struktur dan komposisi jenis pohon hutan pamah bekas tebangan ilegal (illegal logging) di kelompok hutan Sei Lapan, Sei Serdang, Taman Nasional Gunung Leuser, Sumatera Utara.

\section{BAHAN DAN METODE}

\section{A. Lokasi dan Waktu Penelitian}

Penelitian dilakukan pada bulan Juni 2008 di Taman Nasional Gunung Leuser di hutan primer bekas tebangan ilegal (illegal logging) tahun 1995/1996, yaitu pada koordinat $3^{\circ} 45^{\prime} 53,5^{\prime \prime}$ Lintang Selatan dan 98 $05^{\prime} 12,1^{\prime \prime}$ Bujur Timur (Gambar 1). Secara administrasi kehutanan lokasi ini termasuk Resort Cinta Raja, seksi enam wilayah Besitang, bidang tiga Stabat, Balai Besar TNGL dan menurut administrasi pemerintahan terletak di Desa Mekar Makmur, Kecamatan Sei Lepan, Kabupaten Langkat, Sumatera Utara.

Lokasi penelitian terletak pada ketinggian 237,6 $\mathrm{m}$ di atas permukaan laut dan merupakan hutan hujan tropika dataran rendah. Kondisi topografinya bergelombang dengan kelerengan antara 8$35 \%$. Tanah di lokasi penelitian termasuk tipe tropodult (USDA) atau sama dengan podsolik merah kuning (Pusat Penelitian Tanah dan Agroklimat, 1993; Soil Survey Staff, 2003). Material bahan induk terdiri dari batuan asam (acid tuff), batu pasir 


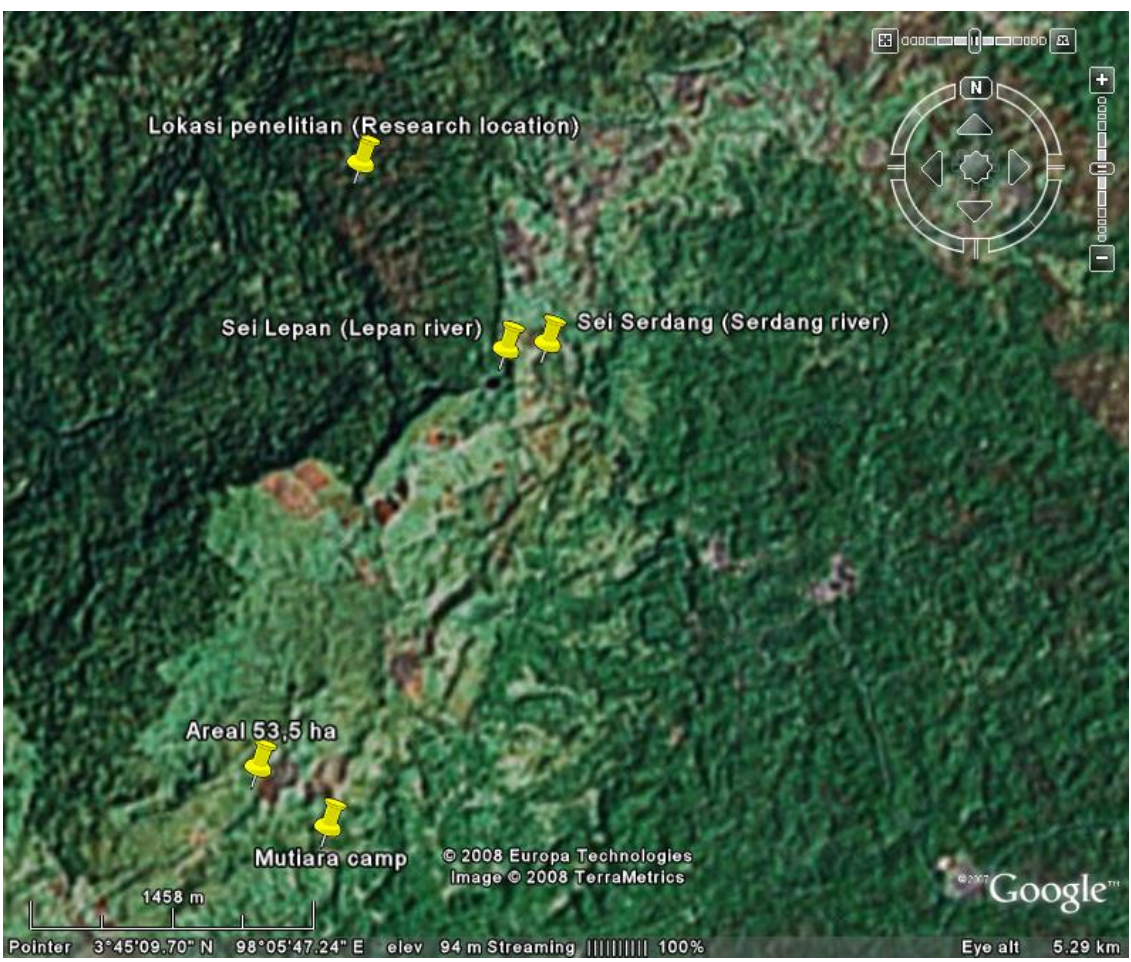

Gambar (Figure) 1. Lokasi penelitian (Study site)

(sandstone), dan deposit pasir (sand deposit). Solum tanah tebal, berwarna merah sampai kuning dengan variabel tekstur konsisten, asam, kandungan nutrisi rendah dengan permeabilitas rendah sampai medium dan sangat mudah tererosi.

Iklim daerah ini menurut klasifikasi Schmitd dan Ferguson (1951) termasuk tipe iklim A dengan curah hujan rata-rata per tahun $3.300 \mathrm{~mm}$ dengan intensitas hujan sebesar 16 dan nilai Q sebesar 2,4\%. Suhu udara rata-rata berkisar antara 25$28^{\circ} \mathrm{C}$ dan kelembaban udara rata-rata $85 \%$.

\section{B. Bahan dan Alat Penelitian}

Bahan penelitian adalah tegakan hutan illegal logging seluas satu hektar yang merupakan bagian dari \pm 75 ha yang tersebar di Resort Cinta Raja, seksi enam wilayah Besitang, bidang tiga Stabat, Balai Besar Taman Nasional Gunung Leuser.

Alat yang digunakan dalam penelitian ini, yaitu GPS (global positioning system), meteran, diameter tape, tali plastik, alat ukur tinggi pohon, pisau/gunting stek, kantong plastik, alkohol, kertas koran, etiket gantung untuk herbarium, dan alat-alat tulis.

\section{Rancangan Penelitian dan Pengam- bilan Contoh}

Penentuan plot penelitian dilakukan secara acak dari luas hutan alam primer illegal logging seluas \pm 75 ha yang dicuplik seluas satu ha dianggap dapat mewakili tegakan tersebut. Satuan contoh berbentuk bujur sangkar dengan ukuran $100 \mathrm{~m} \mathrm{x}$ $100 \mathrm{~m}$ (satu ha). Di dalam plot bujur sangkar tersebut dibuat sub-plot ukuran $20 \mathrm{~m} \times 20 \mathrm{~m}$, dengan demikian terdapat 25 sub plot. Semua pohon dan pancang diukur diameter, tinggi, dan dicatat nama jenisnya, sedangkan tingkat semai dihitung jumlah dan nama jenisnya. Jenis-jenis tersebut diambil contoh materialnya dan diidentifikasi di Laboratorium Botani dan Ekologi Hutan, Pusat Penelitian dan Pengembangan Hutan dan Konservasi Alam, Bogor. Kriteria untuk tingkat pohon, pancang, dan semai adalah sebagai berikut (Kartawinata et al., 1976):

1. Pohon, dengan kriteria diameter setinggi dada $(1,3 \mathrm{~m}) \geq 10 \mathrm{~cm}$, bila pohon berbanir diameter diukur $20 \mathrm{~cm}$ di atas banir, ukuran plot $20 \mathrm{~m}$ x $20 \mathrm{~m}$. 
2. Pancang, yaitu permudaan yang tingginya $>1,5 \mathrm{~m}$ sampai pohon muda dengan diameter $<10 \mathrm{~cm}$, ukuran plot 5 $\mathrm{m} \times 5 \mathrm{~m}$.

3. Semai, yaitu permudaan mulai dari kecambah sampai tinggi $\leq 1,5 \mathrm{~m}$, ukuran plot $2 \mathrm{~m} \times 2 \mathrm{~m}$.

\section{Analisis Data}

Data yang diperoleh dianalisis untuk menentukan jenis-jenis yang dominan. Jenis dominan merupakan jenis yang mempunyai nilai penting tertinggi di dalam tipe vegetasi yang bersangkutan (Kusmana, 1997). Jenis dominan tersebut dapat diperoleh dengan analisis indeks nilai penting (\%) sebagai penjumlahan kerapatan relatif, dominasi relatif, dan frekuensi relatif dari masing-masing jenis yang terdapat dalam sampel plot (Soerianegara dan Indrawan, 1982).

\section{Potensi Jenis Vegetasi}

Potensi jenis vegetasi dalam plot penelitian dikategorikan ke dalam tiga tingkat pertumbuhan yaitu semai, pancang, dan pohon yang masing-masing dihitung per satuan luas (ha).

\section{Potensi Tegakan}

Potensi tegakan dihitung meliputi volume tegakan dan jumlah batang per ha yang diklasifikasikan menurut kelas dia- meter: $10-19 \mathrm{~cm}, 20-29 \mathrm{~cm}, 30-39 \mathrm{~cm}$, 40-49 cm, 50-59 cm, dan $\geq 60 \mathrm{~cm}$.

Volume diketahui melalui perhitungan dengan menggunakan rumus sebagai berikut:

$\mathrm{V}=1 / 4 . \pi \cdot \mathrm{d}^{2} \cdot \mathrm{t} \cdot \mathrm{f}$

Dimana:

$\mathrm{V}=$ Volume pohon total $\left(\mathrm{m}^{3}\right)$,

$\pi=$ Konstanta $(3,141592654)$,

$\mathrm{d}$ = Diameter pohon setinggi dada atau $20 \mathrm{~cm}$ di atas banir $(\mathrm{cm})$,

$\mathrm{t}=$ Tinggi pohon bebas cabang $(\mathrm{m})$,

$\mathrm{f}=$ Angka bentuk pohon $(0,6)$.

\section{HASIL DAN PEMBAHASAN}

\section{A. Komposisi dan Potensi Vegetasi}

\section{Komposisi Jenis}

Berdasarkan hasil identifikasi jenis dan suku tumbuhan (Lampiran 1), dijumpai 110 jenis pohon tergolong dalam 34 suku, dimana suku yang mempunyai jenis terbanyak adalah Euphorbiaceae, Dipterocarpaceae, dan Myrtaceae (Lampiran 2).

Pada penelitian ini dijumpai pohon berjumlah 687 batang/ha dalam 25 subplot berukuran $20 \mathrm{~m}$ x $20 \mathrm{~m}$. Sebaran jumlah jenis dalam sub-plot mengikuti kurva jenis pohon sebagaimana terlihat pada Gambar 2.

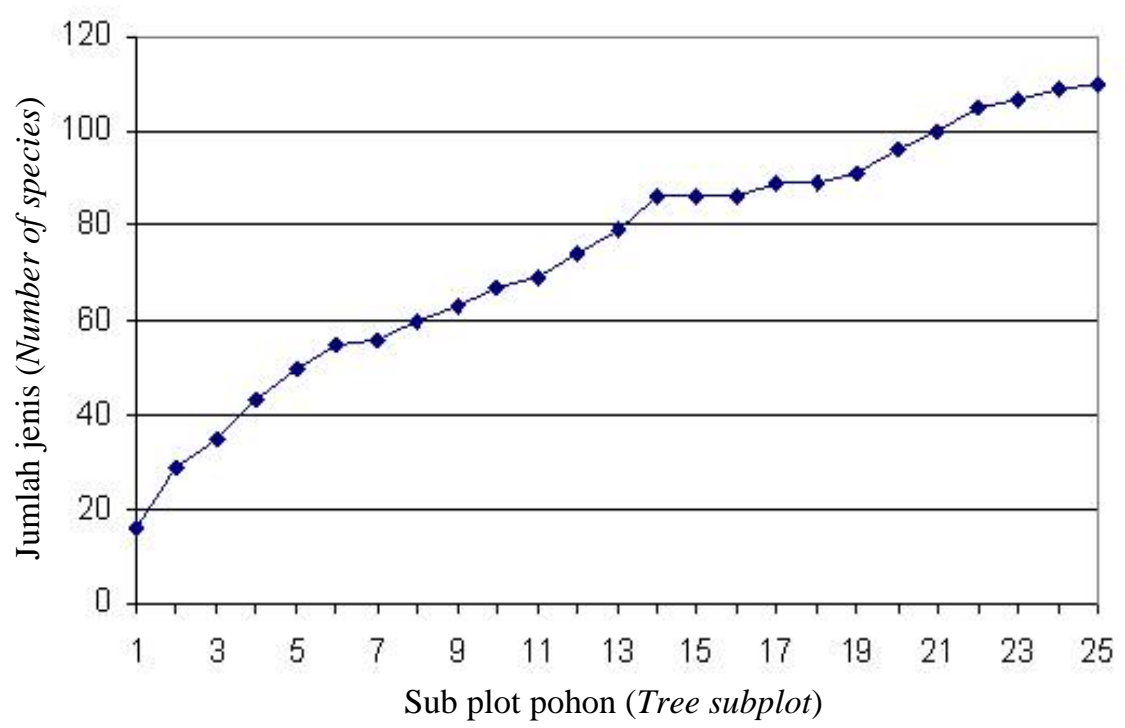

Gambar (Figure) 2. Kurva jenis pohon berdiameter $\geq 10 \mathrm{~cm}$ dalam 25 sub plot (20 m x $20 \mathrm{~m})$ m) di lokasi penelitian (Species area curve of trees with diameter of $\geq$ $10 \mathrm{~cm}$ in $25 \mathrm{sub}$-plots (20 $m \times 20 \mathrm{~m}$ ) at the study site) 
Hasil penelitian menunjukkan dari 110 jenis pohon berdiameter $\geq 10 \mathrm{~cm}$ terdapat 12 jenis pohon dominan dengan INP $>$ 5\%. Tegakan hutan didominasi oleh Macaranga hoseii dengan INP 34,66\%. Kerapatan dan basal area jenis dominan tersebut tertera pada Tabel 1.

\section{Potensi Jenis Vegetasi}

Pada lokasi penelitian di Desa Mekar Makmur TNGL terdapat empat jenis $M a-$ caranga, yaitu $M$. bancana, M. conifera, M. Gigantea, dan M. hoseii. Penelitian Priatna et al. (2006) di kawasan hutan bekas tebangan di Sekundur TNGL berumur 22 tahun, menunjukkan bahwa jenis yang jumlahnya dominan adalah $M$. diepenhorstii dengan kerapatan 34 pohon/ha dan INP 12,4\%, kemudian diikuti Shorea kunstleri, kerapatan 23,5 pohon/ha dengan INP 24,4\%. Di lokasi penelitian Desa Mekar Makmur, kerapatan M. hoseii adalah 137 pohon/ha dengan bidang dasar 2,46 $\mathrm{m}^{2} /$ ha sedangkan bidang dasar terluas berikutnya adalah Shorea sp. dan Shorea inappendiculata yaitu $2,40 \mathrm{~m}^{2} / \mathrm{ha}$ dan 2,34 $\mathrm{m}^{2} /$ ha dengan kerapatan masing-masing 39 pohon/ha dan 6 pohon/ha. Kerapatan pohon dari 12 jenis pohon dominan adalah 371 pohon/ha dan 54\% dari jumlah total pohon untuk 110 jenis pohon di lokasi penelitian (687 pohon). Keadaan ini lebih tinggi dari kerapatan pohon di hutan sekunder hasil penelitian Priatna et al. (2006) yaitu 572,5 pohon/ha dengan 133 jenis pohon. Perbandingan jumlah jenis dan kerapatan pohon dari beberapa areal lain disajikan pada Tabel 2.

Tabel (Table) 1. Jenis-jenis pohon dominan berdiameter $\geq 10 \mathrm{~cm}$ (INP $>5 \%$ ) di lokasi penelitian (The dominant species trees with diameter of $\geq 10 \mathrm{~cm}(I V I>5 \%)$ at the study site)

\begin{tabular}{clcc}
\hline No. & \multicolumn{1}{c}{ Jenis (Species) } & $\begin{array}{c}\text { Kerapatan } \\
(\text { Density }) \\
1 \mathrm{ha}\end{array}$ & $\begin{array}{c}\text { Luas bidang dasar } \\
(\text { Basal area }) \\
\left(\mathrm{m}^{2} / \mathrm{ha}\right)\end{array}$ \\
\hline 1 & Macaranga hoseii King ex Hook.f. & 137,0 & 2,46 \\
2 & Cleistanthus sp. & 43,0 & 0,68 \\
3 & Shorea sp. & 39,0 & 2,40 \\
4 & Melicope glabra (Blume) T.G.Hortley & 33,0 & 0,41 \\
5 & Shorea multiflora (Burk) Symington & 30,0 & 1,10 \\
6 & Pentace cf. borneensis Pierre & 20,0 & 1,02 \\
7 & Durio excelsus Griff. & 17,0 & 1,00 \\
8 & Syzygium sp. & 13,0 & 0,43 \\
9 & Diospyros buxyfolia (Blume) Hiern & 13,0 & 0,48 \\
10 & Messua sp. & 11,0 & 0,38 \\
11 & Syzygium tawahense (Korth.) Merr. \& Perry & 9,0 & 1,31 \\
12 & Shorea inappendiculata Burck & 6,0 & 2,34 \\
\hline \multicolumn{2}{r}{ Jumlah (Total) } & 371,0 & 14,00 \\
\hline
\end{tabular}

Tabel (Table) 2. Perbandingan kerapatan dan jumlah jenis pohon dengan diameter $\geq 10 \mathrm{~cm}$ pada lokasi penelitian dan lokasi lain (Comparison of densities and number of tree species with diameter of $\geq 10 \mathrm{~cm}$ found in the study site and other location)

\begin{tabular}{|c|c|c|c|c|c|}
\hline Lokasi (Location) & $\begin{array}{l}\mathrm{DPL}(A l t) \\
\quad(\mathrm{m})\end{array}$ & $\begin{array}{c}\text { Luas plot } \\
\text { (Plot size) } \\
(\mathrm{Ha})\end{array}$ & $\begin{array}{l}\text { Kerapatan } \\
\text { (Density) } \\
\text { (N/ha) }\end{array}$ & $\begin{array}{c}\text { Jumlah spesies } \\
\text { (Number of } \\
\text { species) }\end{array}$ & Sumber (Source) \\
\hline $\begin{array}{l}\text { Desa Mekar Mak- } \\
\text { mur, TNGL }\end{array}$ & 237,6 & 1 & 687 & 110 & $\begin{array}{l}\text { Penelitian sekarang } \\
\text { (Present study) }\end{array}$ \\
\hline $\begin{array}{l}\text { Aek Nangali, Ba- } \\
\text { tang Gadis }\end{array}$ & 650 & 1 & 583 & 184 & $\begin{array}{l}\text { Kartawinata et al. } \\
\text { (2004) }\end{array}$ \\
\hline Sekundur, TNGL & $75-100$ & 2 & 572,5 & 133 & Priatna et al. (2006) \\
\hline Ketambe, NAD & $350-450$ & 1,6 & 420 & 94 & Abdulhadi (1991) \\
\hline $\begin{array}{l}\text { Seturan Malinau, } \\
\text { Kaltim }\end{array}$ & 100 & 1 & 759 & 205 & Sheil et al. (2010) \\
\hline $\begin{array}{l}\text { Gunung Mulu, } \\
\text { Serawak }\end{array}$ & 50 & 1 & 615 & 223 & Proctor et al. (1983) \\
\hline
\end{tabular}


Di lokasi penelitian TNGL terdapat 19 jenis Euphorbiaceae, dengan jenis dominan $M$. hoseii (137 pohon/ha) sedangkan di kawasan Sukundur terdapat 18 jenis Euphorbiaceae dengan kerapatan 124 pohon/ha. Kerapatan $M$. hoseii meningkat dari 10 pohon/ha pada awal tebangan menjadi 34 pohon/ha setelah tebangan 22 tahun (Priatna et al., 2006). Di hutan primer Taman Nasional Batang Gadis (TNBG) terdapat 184 jenis pohon dalam 41 suku dengan kerapatan 583 pohon/ha. Dalam hal ini ada empat jenis Macaranga, yaitu M. gigantea, M. hoseii, M. hipoleuca, dan M. lowii, INP jenis ini berkisar antara 0,69-6,7\% dengan kerapatan 1-4 pohon/ha, sedangkan Dipterocarpaceae terdapat 16 jenis dengan kerapatan berkisar 1-24 pohon/ha dan INP 0,8330,29\%. Jenis dominan adalah Shorea gibbosa 24 pohon/ha dengan INP 30,29\% (Kartawinata et al., 2004). Di lokasi penelitian Desa Mekar Makmur TNGL juga terdapat empat jenis Macaranga dengan kerapatan pohon tertinggi M. hoseii (137 pohon/ha). Selanjutnya Shorea sp. dan $S$. multiflora dengan kerapatan dan INP secara berurutan yaitu 39 pohon/ha dan 30 pohon/ha dengan INP 19,88\% dan 12,29\%. Adapun jenis pohon dari suku Dipterocarpaceae dominan dengan jumlah bidang dasar 2,4 $\mathrm{m}^{2} / \mathrm{ha}$ dan $1,10 \mathrm{~m}^{2} /$ ha kemudian diikuti $S$. inappendiculata bidang dasar $2,34 \mathrm{~m}^{2} /$ ha dengan jumlah pohon relatif rendah, yaitu 6 pohon/ha.

Hasil analisis vegetasi dengan jenis-jenis pohon dominan yang mewakili tingkat semai, pancang, dan pohon dengan INP > 5\% disajikan pada Tabel 3 .

\section{B. Struktur Tegakan dan Regenerasi}

Struktur tegakan hutan adalah sebaran individu tumbuhan dalam lapisan tajuk (Richard, 1964) dan dapat diartikan sebaran pohon per satuan luas dalam berbagai kelas diameternya (Meyer et al., 1961). Secara keseluruhan struktur tegakan pohon dalam plot penelitian tersaji pada Gambar 3.

Tabel (Table) 3. Jenis-jenis pohon dominan (INP > 5\%) di lokasi penelitian (The dominant tree species (IVI $>5 \%)$ at the study site)

\begin{tabular}{|c|c|c|c|c|c|}
\hline \multirow[b]{2}{*}{ No. } & \multirow[b]{2}{*}{ Nama botani (Botanical name) } & \multicolumn{3}{|c|}{ INP (IVI) (\%) } & \multirow[b]{2}{*}{ Famili (Family) } \\
\hline & & $\begin{array}{c}\text { Semai } \\
\text { (Seedling) }\end{array}$ & $\begin{array}{l}\text { Pancang } \\
\text { (Sapling) }\end{array}$ & $\begin{array}{l}\text { Pohon } \\
\text { (Tree) }\end{array}$ & \\
\hline 1. & Agrostistachys borneensis Becc. & 9,89 & 17,57 & - & Euphorbiaceae \\
\hline 2. & Aporosa alia A.Schot & - & 8,34 & - & Euphorbiaceae \\
\hline 3. & Archidendron sp. & 37,27 & 35,0 & - & Leguminosae \\
\hline 4. & Canarium denticulatum Blume & - & 6,35 & - & Burseraceae \\
\hline 5. & Cleistanthus sp. & 12,92 & 30,75 & 12,70 & Euphorbiaceae \\
\hline 6. & Diospyros polyalthioides Hiern & 14,34 & 17,83 & - & Ebenaceae \\
\hline 7. & Diospyros sp. & 10,49 & 6,93 & - & Ebenaceae \\
\hline 8. & Diospyros buxyfolia (Blume) Hiem & - & - & 5,57 & Ebenaceae \\
\hline 9. & Dipterocarpus sp. & 10,49 & 6,93 & - & Dipterocarpaceae \\
\hline 10. & Durio excelsus Griff. & 9,48 & - & - & Bombacaceae \\
\hline 11. & Garcinia sp. & 13,10 & - & - & Guttiferae \\
\hline 12. & Garcinia sp. & 9,06 & 5,13 & - & Guttiferae \\
\hline 13. & $\begin{array}{l}\text { Glochidion obscurum (Roxb. Ex Willd.) } \\
\text { Blume }\end{array}$ & 7,79 & 20,46 & - & Euphorbiaceae \\
\hline 14. & Macaranga hoseii King ex Hook.f. & - & 11,73 & 34,66 & Euphorbiaceae \\
\hline 15. & Melicope glabra (Blume) T.G.Hortley & - & - & 9,91 & Rutaceae \\
\hline 16. & Pentace cf. borneensis Pierre & - & 6,82 & 10,03 & Tiliaceae \\
\hline 17. & Shorea inappendiculata Burck & - & - & 11,91 & Dipterocarpaceae \\
\hline 18. & Shorea multiflora (Burk) Symington & - & - & 12,29 & Dipterocarpaceae \\
\hline 19. & Shorea sp. & 9,40 & 15,49 & 19,88 & Dipterocarpaceae \\
\hline 20. & Syzygium sp. & - & 10,69 & - & Myrtaceae \\
\hline 21. & $\begin{array}{l}\text { Syzygium tawahense (Korth.) Merr. \& } \\
\text { Perry }\end{array}$ & - & 8,01 & - & Myrtaceae \\
\hline 22. & Vatica sp. & 9,48 & 14,19 & - & Dipterocarpaceae \\
\hline
\end{tabular}




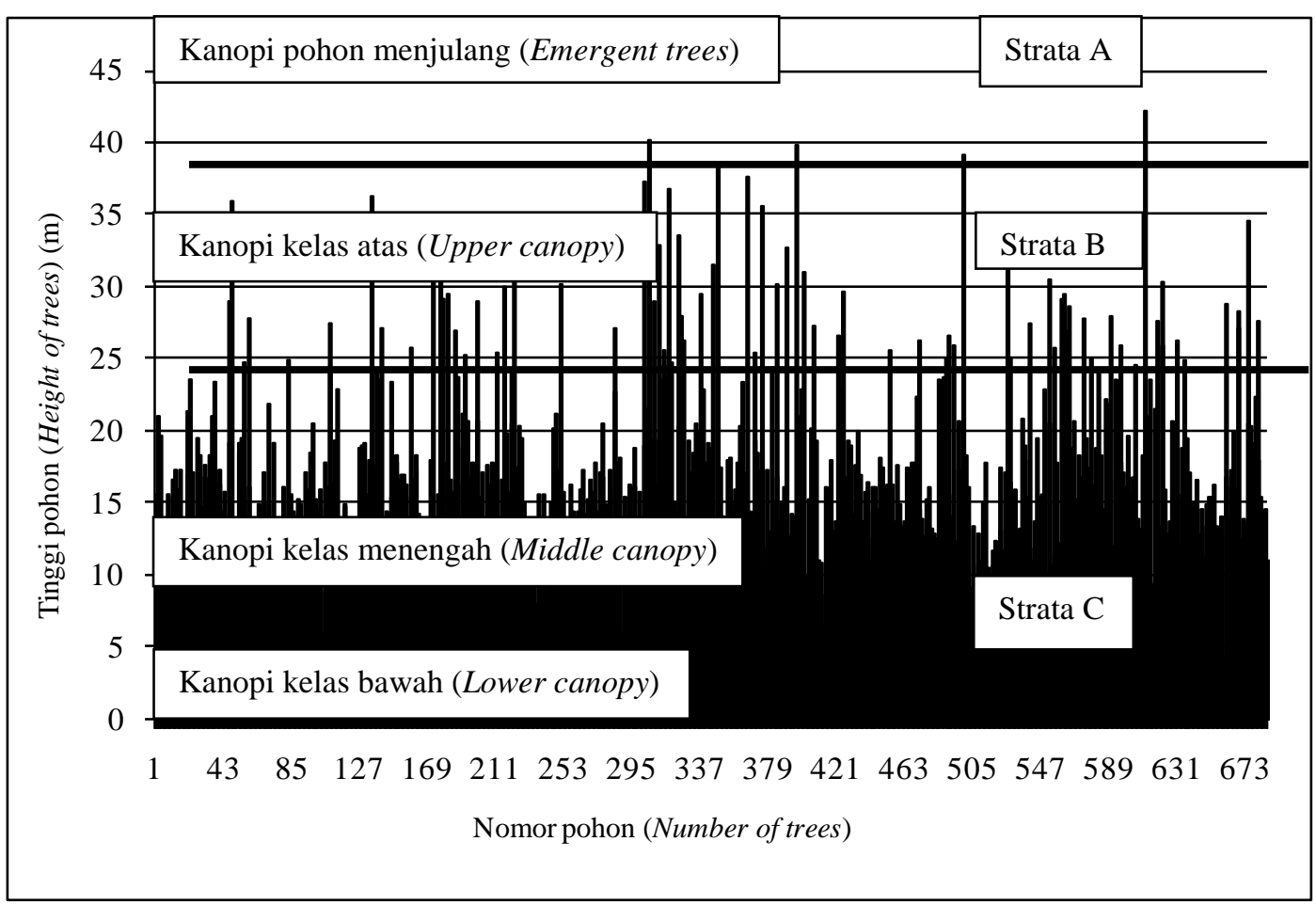

Gambar (Figure) 3. Profil tegakan hutan di lokasi penelitian (Canopy position of trees at study site)

Jenis pohon yang paling dominan pada strata A (> $40 \mathrm{~m}$ ) yaitu Shorea inappendiculata Burck. (42,2 m); sedangkan strata B (30-40 m) dan strata C (20-30 m) masing-masing didominasi oleh jenis Cleistanthus sp.1 (39,8 m) dan jenis Macaranga bancana (Miq.) Muell.Arg. (29,7 m) (Gambar 3).

Hasil penelitian sebaran semua pohon untuk kelas diameter $10-19 \mathrm{~cm}, 20-29 \mathrm{~cm}$, 30-39 cm, 40-49 cm, 50-59 cm, dan diameter $\geq 60 \mathrm{~cm}$ di lokasi penelitian ditampilkan pada Gambar 4. Jumlah batang per hektar di hutan bekas tebangan dipengaruhi oleh jumlah tegakan awal sebelum ditebang, intensitas penebangan yaitu jumlah pohon yang ditebang dalam kurun waktu tertentu.

Struktur tegakan hutan bekas tebangan tidak selalu sama walaupun di tempat yang sama. Hal ini disebabkan oleh adanya perbedaan kemampuan pohon dalam memanfaatkan energi matahari, unsur hara/ mineral, air serta sifat kompetisi; oleh karena itu susunan pohon di dalam tegakan hutan akan membentuk sebaran kelas diameter yang bervariasi (Ewusie, 1980).
Dari Gambar 4 dapat dikemukakan bahwa struktur tegakan hutan di lokasi penelitian menunjukkan jumlah pohon yang semakin berkurang dari kelas diameter kecil ke kelas diameter besar, sehingga bentuk kurva pada umumnya dicirikan oleh jumlah sebaran yang menyerupai "J" terbalik. Secara umum struktur tegakan hutan di lokasi penelitian menunjukkan karakteristik yang demikian, sehingga dapat dikatakan hutan tersebut masih normal. Sebaliknya Gambar 5 menunjukkan bahwa volume per hektar tegakan berdiameter besar $(\geq 60 \mathrm{~cm})$ lebih tinggi dibandingkan dengan volume per hektar pada tegakan dengan diameter di bawahnya.

Regenerasi merupakan fenomena alam di mana pohon yang muda akan menggantikan pohon dewasa karena sesuatu sebab, misalnya ditebang, terbakar, tumbang (bencana alam) atau mati secara fisiologis. Adapun regenerasi jenis tumbuhan yang lengkap (ada di setiap strata: pohon, pancang dan semai), disajikan pada Tabel 4, pancang tanpa regenerasi (Tabel 5), dan 
semai yang tidak dijumpai di tingkat pancang maupun pohon (Tabel 6).

Pada Tabel 4, Tabel 5, dan Tabel 6 dapat dikemukakan bahwa jenis yang mendominasi regenerasi lengkap: tingkat semai dan pancang yaitu Archidendron sp. (INP 37,27\% dan 35, 0\%), sedangkan untuk tingkat pohon yaitu Shorea sp. Dengan INP 19,88\%. Pada regenerasi pan- cang didominasi berturut-turut oleh jenis Vatica sp. dengan INP 4,19\%, Knema curtisii (King) Warb. INP 3,56\%, dan Heritiera sumatrana INP 2,01\%. Pada regenerasi tingkat semai didominasi oleh jenis Xanthophyllum sp. dengan INP 2,85\%, Rinorea sp. INP 2,10\%, serta Horsfieldia sp.dan Dysoxylum sp. INP masing-masing sebesar 1,76\%.

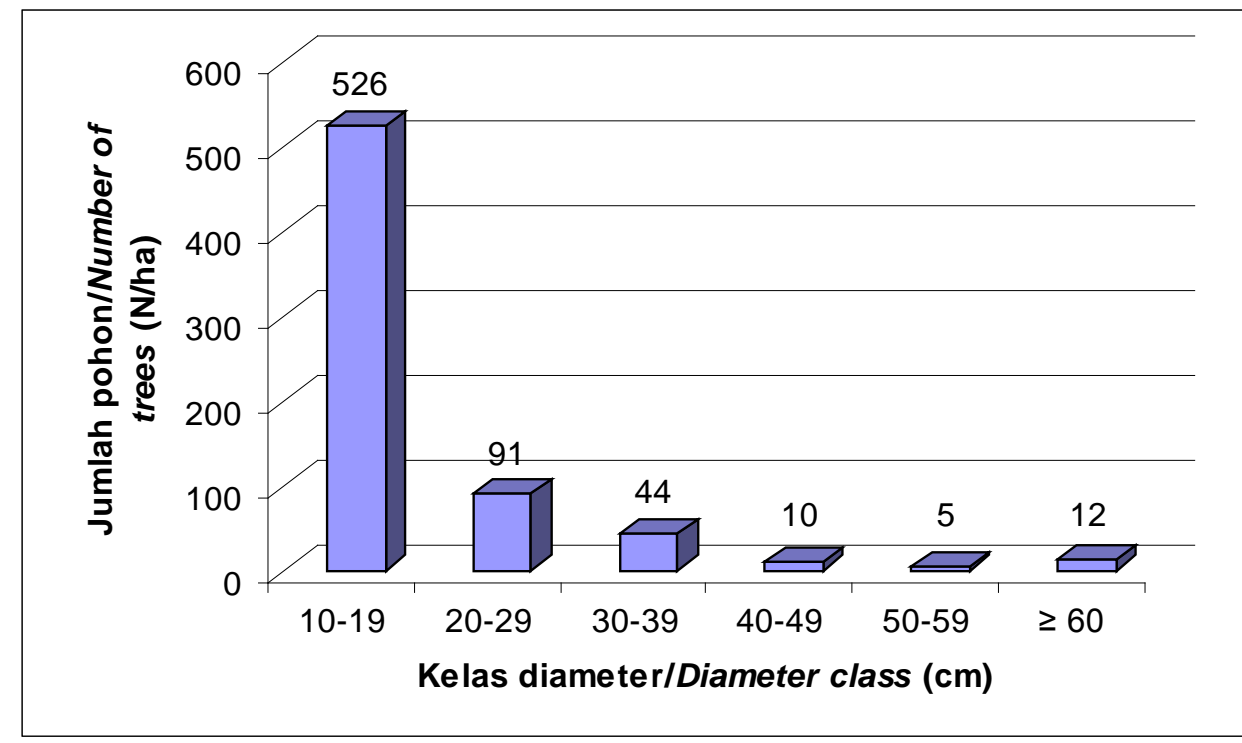

Gambar (Figure) 4. Struktur tegakan berdasarkan hubungan antara kelas diameter dengan jumlah pohon di lokasi penelitian (Stand structure based on the relationship between diameter class and number of trees at the study site)

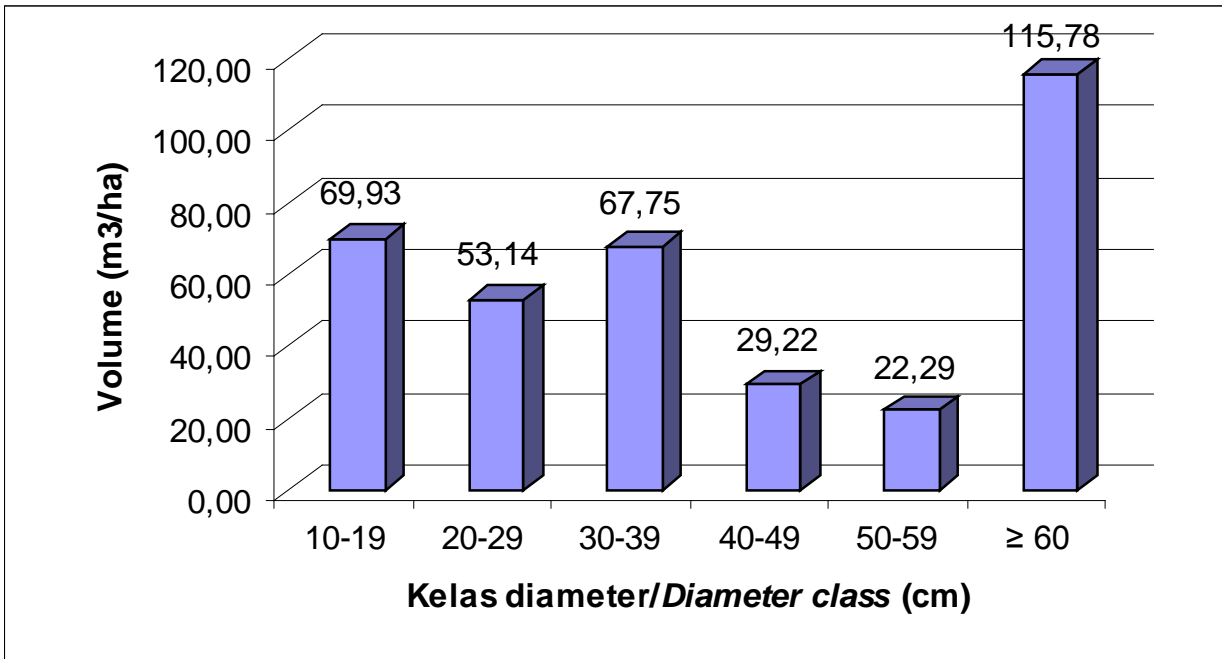

Gambar (Figure) 5. Struktur tegakan berdasarkan hubungan antara kelas diameter dengan volume/ha di lokasi penelitian (Stand structure based on the relationship between diameter class and stand volume at the study site) 
Tabel (Table) 4. Jenis pohon yang dijumpai di semua tingkatan pertumbuhan di lokasi penelitian (Tree species found in all vegetation stages at the study site)

\begin{tabular}{|c|c|c|c|c|c|}
\hline \multirow{2}{*}{ No. } & \multirow{2}{*}{ Nama botani (Botanical name) } & \multirow[b]{2}{*}{ Famili (Family) } & \multicolumn{3}{|c|}{ INP (IVI) (\%) } \\
\hline & & & $\begin{array}{c}\text { Semai } \\
\text { (Seedling) }\end{array}$ & $\begin{array}{l}\text { Pancang } \\
\text { (Sapling) }\end{array}$ & $\begin{array}{l}\text { Pohon } \\
\text { (Tree) }\end{array}$ \\
\hline 1 & Aporosa alia A.Schot & Euphorbiaceae & 1,76 & 8,34 & 4,24 \\
\hline 2 & Archidendron sp. & Leguminosae & 37,27 & 35,00 & 3,52 \\
\hline 3 & Cleistanthus sp. & Euphorbiaceae & 12,92 & 30,75 & 12,70 \\
\hline 4 & Diospyros polyalthioides Hiern & Ebenaceae & 14,34 & 17,83 & 3,11 \\
\hline 5 & Dipterocarpus sp. & Dipterocarpaceae & 10,49 & 6,93 & 4,59 \\
\hline 6 & Garcinia sp. & Guttiferae & 13,10 & 4,07 & 2,03 \\
\hline 7 & Garcinia sp.1 & Guttiferae & 9,06 & 5,13 & 3,30 \\
\hline 8 & Garcinia sp.2 & Guttiferae & 6,70 & 2,19 & 1,71 \\
\hline 9 & Glochidion obscurum (Roxb. Ex Willd.) Blume & Euphorbiaceae & 7,79 & 20,46 & 1,91 \\
\hline 10 & Gonystylus affinis Radlk & Thymelaeaceae & 1,42 & 8,48 & 2,13 \\
\hline 11 & Messua sp. & Guttiferae & 4,27 & 2,03 & 5,10 \\
\hline 12 & Pentace cf. borneensis Pierre & Tiliaceae & 1,42 & 6,82 & 10,03 \\
\hline 13 & $\begin{array}{l}\text { Scaphium macropodum (Miq.) Beumee ex } \\
\text { K.Heyne }\end{array}$ & Sterculiaceae & 2,10 & 2,19 & 2,51 \\
\hline 14 & Shorea multiflora (Burk) Symington & Dipterocarpaceae & 3,52 & 3,73 & 12,29 \\
\hline 15 & Shorea sp. & Dipterocarpaceae & 9,40 & 15,48 & 19,88 \\
\hline 16 & Syzygium sp. & Myrtaceae & 4,27 & 4,63 & 0,59 \\
\hline 17 & Syzygium sp.1 & Myrtaceae & 2,85 & 10,69 & 6,11 \\
\hline 18 & Vatica sp. & Dipterocarpaceae & 9,48 & 14,19 & 2,56 \\
\hline
\end{tabular}

Tabel (Table) 5. Jenis pancang tanpa regenerasi (Sapling species without regeneration)

\begin{tabular}{cllc}
\hline No. & Nama botani (Botanical name) & Famili (Family) & INP (IVI) (\%) \\
\hline 1 & Elaeocarpus cupreus Merr & Elaeocarpaceae & 1,99 \\
2 & Heritiera sumatrana & Sterculiaceae & 2,01 \\
3 & Ixora sp. & Rubiaceae & 1,99 \\
4 & Knema curtisii (King) Warb. & Myristicaceae & 3,56 \\
5 & Vatica sp. & Dipterocarpaceae & 4,19 \\
\hline
\end{tabular}

Tabel (Table) 6. Jenis-jenis semai yang tidak dijumpai di tingkat pancang maupun pohon (Seedling species not found in the sapling and tree stage)

\begin{tabular}{cllc}
\hline No. & \multicolumn{1}{c}{ Nama botani (Botanical name) } & \multicolumn{1}{c}{ Famili (Family) } & INP (IVI) (\%) \\
\hline 1 & Acmena sp. & Myrtaceae & 1,42 \\
2 & Antidesma sp. & Euphorbiaceae & 1,42 \\
3 & Blumeodendron sp. & Euphorbiaceae & 1,42 \\
4 & Dysoxylum sp. & Meliaceae & 1,76 \\
5 & Glochidion sericeum (Blume) Zoll. \& Merr. & Euphorbiaceae & 1,42 \\
6 & Horsfieldia sp. & Myristicaceae & 1,76 \\
7 & Litsea sp. & Lauraceae & 1,42 \\
8 & Rinorea sp. & Violaceae & 2,10 \\
9 & Xanthophyllum sp. & Polygalaceae & 2,85 \\
\hline
\end{tabular}

\section{KESIMPULAN DAN SARAN}

\section{A. Kesimpulan}

1. Berdasarkan hasil penelitian di kawasan hutan Sei Lepan, Taman Nasional Gunung Leuser, Sumatera Utara
(Desa Mekar Makmur) pada plot seluas satu ha tercatat 110 jenis pohon berdiameter $\geq 10 \mathrm{~cm}$ dan berjumlah 687 pohon, tergolong dalam 34 suku di mana suku yang mempunyai jenis terbanyak adalah Euphorbiaceae, Dipterocarpaceae, dan Myrtaceae. 
Jenis-jenis yang dominan berturut-turut adalah Macaranga hoseii King ex Hook.f., Shorea sp., dan Shorea multiflora (Burk) Symington.

2. Kerapatan pancang dan semai sebesar 12.800 batang/ha dan 29.700 batang/ha. Potensi pohon berdiameter $\geq$ $10 \mathrm{~cm}$ di lokasi penelitian sebesar $358,11 \mathrm{~m}^{3} / \mathrm{ha}$.

3. Potensi tegakan didominasi oleh kelas diameter $\geq 60 \mathrm{~cm}$ yaitu sebesar 115,6 $\mathrm{m}^{3}$ per hektar lebih tinggi dibandingkan dengan kelas diameter di bawahnya.

4. Jenis yang mendominasi regenerasi lengkap, yaitu ada pada setiap tingkat (pohon, pancang, dan semai); untuk tingkat semai dan pancang yaitu Archidendron sp.1 (INP 37,27\% dan 35,0\%), tingkat pohon Shorea sp. dengan INP 19,88\%. Pohon tanpa regenerasi, baik di tingkat pancang maupun semai didominasi oleh jenis Shorea inappendiculata Burck. dengan INP 11,91\%, Melicope glabra (Blume) T.G.Hortley. INP 9,91\%, dan jenis Durio excelsus Griff. INP 9,48\%. Tingkat pancang didominasi berturut-turut oleh jenis Vatica sp. dengan INP 4,19\%, Knema curtisii (King) Warb. INP 3,56\%, dan Heritiera sumatrana INP 2,01\%, sedangkan tingkat semai didominasi oleh jenis Xanthophyllum sp. dengan INP 2,85\%, Rinorea sp. INP 2,10\%, serta Horsfieldia sp. dan Dysoxylum sp. INP masing-masing sebesar $1,76 \%$.

\section{B. Saran}

Lokasi penelitian adalah bagian penting dari Taman Nasional Gunung Leuser karena berupa kawasan hutan pamah yang kaya akan keanekaragaman hayati. Oleh karena itu, perlindungan kawasan hutan Sei Lepan dari kegiatan perambahan mutlak diperlukan di samping perlunya upaya segera kegiatan restorasi.

\section{DAFTAR PUSTAKA}

Abdulhadi, R. 1991. A Meliaceae Forest in Ketambe, G. Leuser National Park, Sumatra, Indonesia, with Special Reference to the Status of Dipterocarp, Species. In Soerianegara, I., S. Tjitrosomo, R.C. Umaly, and I. Umboh (eds.). Proceedings of the Fourth Round-Table Conference on Dipterocarps, Bogor, Indonesia, 1215 December 1989. Biotrop Special Publication 41: 307-315.

Ewusie, J.Y. 1980. Pengantar Ekologi Tropika (Terjemahan). ITB-Press. Bandung.

Kartawinata, K., S. Soenarko., I G.M. Tantra, dan T. Samingan. 1976. Pedoman Inventarisasi Flora dan Ekosistem. Direktorat Perlindungan dan Pengawetan Alam, Bogor.

Kartawinata, K., I. Samsoedin, N.M. Heriyanto, and J.J. Afriastini. 2004. A Tree Species Inventory in a OneHectare Plot at the Batang Gadis National Park, North Sumatra, Indonesia. A Journal on Taxonomic Botany, Plant Sociology and Ecology. Reinwardtia 12(2): 145-157.

Keputusan Menteri Kehutanan No. 159/ Menhut-II/2004 Tentang Restorasi Ekosistem di Hutan Produksi. Jakarta 4 Juni 2004.

Kusmana, C. 1997. Metode Survei Vegetasi. IPB Press. Bogor.

Meyer, H.A., A.B. Recknagel, and D.D. Stevenson. 1961. Forest Management. The Roland Press Company, New York.

Proctor, J., J.M. Anderson, P. Chai, and H.M. Wallack. 1983. Ecological Stu-dies in Four Constasting Tropical Lowland Rain Forests in Gunung Mulu National Park. I. Forest Environment, Structure and Floristics. Journal of Ecology 71: 237260. 
Priatna, D., K. Kartawinata, and R. Abdulhadi. 2006. Recovery of a Lowland Dipterocarp Forest Twenty Two Years After Selective Logging at Sekundur, Gunung Leuser National Park, North Sumatra, Indonesia. A Journal on Taxonomic Botany, Plant Sociology and Ecology. Reinwardtia 12(3): 237-251.

Pusat Penelitian Tanah dan Agroklimat. 1993. Peta Tanah Pulau Sumatera. Badan Penelitian dan Pengembangan Pertanian, Bogor.

REKI. 2005. Proposal Teknis untuk Pelelangan Ijin Hutan Pemanfaatan Hasil Hutan Kayu dengan Kegiatan Restorasi Ekosistem di Kawasan Hutan Produksi. Bogor.

Richard, P.W. 1964. The Tropical Rain Forest: an Ecological Study. Cambridge the University Press. Cambridge.

Schmidt, F.H. and J.H. Ferguson. 1951. Rainfall Types Based on Wet and Dry Period Ratios for Indonesia with Western New Guinea. Verhand. No. 42 Kementerian Perhu- bungan Djawatan Meteorologi dan Geofisika. Jakarta.

Sheil, D., K. Kartawinata, I. Samsoedin, H. Priyadi and J.J. Afriastini. 2010. The Lowland Forest Tree Community in Malinau, Kalimantan (Indonesian Borneo): results from a one-hectare plot. Plant Ecology and Diversity. Vol. 3, No. 1, February, 59-66.

Soerianegara, I. dan A. Indrawan. 1982. Ekologi Hutan Indonesia. Departemen Manajemen Hutan. Fakultas Kehutanan IPB, Bogor.

Soil Survey Staff. 2003. Keys to Soil Taxonomy, $9^{\text {th }}$ Edition. USDA Natural Resources Conservation Service. Washington D.C.

Wiratno, D. Indriyo, A. Syarifudin, dan A. Kartikasari. 2004. Berkaca di Cermin yang Retak. Refleksi Konservasi dan Implikasi bagi Pengelolaan Taman Nasional (Edisi Kedua). FORest Press, The Gibbon Foundation Indonesia, Departemen Kehutanan, PILI-NGO Movement. 
Lampiran (Appendix) 1. Daftar jenis pohon pada plot satu ha di lokasi penelitian (Tree species listed in a 1ha plot at the study site)

\begin{tabular}{|c|c|c|c|c|c|c|c|c|}
\hline No. & $\begin{array}{c}\text { Famili dan jenis } \\
\text { (Family and species) }\end{array}$ & $\begin{array}{l}\mathrm{K} \\
(D)\end{array}$ & $\begin{array}{c}\mathrm{Kr} \\
(R D)\end{array}$ & $\mathrm{F}$ & $\begin{array}{c}\mathrm{FR} \\
(R F)\end{array}$ & $\begin{array}{c}\mathrm{D} \\
(B A)\end{array}$ & $\begin{array}{c}\mathrm{DR} \\
(R B A)\end{array}$ & $\begin{array}{l}\text { INP (IVI) } \\
(\%)\end{array}$ \\
\hline & Meliaceae & & & & & & & \\
\hline 1. & Aglaia sp. & 1,0 & 0,15 & 0,04 & 0,25 & 0,01 & 0,05 & 0,44 \\
\hline 2. & Aglaia sp.1 & 1,0 & 0,15 & 0,04 & 0,25 & 0,01 & 0,05 & 0,44 \\
\hline 3. & Aglaia sp.2 & 2,0 & 0,29 & 0,08 & 0,49 & 0,10 & 0,41 & 1,20 \\
\hline \multirow[t]{2}{*}{4.} & $\begin{array}{l}\text { Dysoxylum alliaceum } \\
\text { (Blume) Blume }\end{array}$ & 2,0 & 0,29 & 0,08 & 0,49 & 0,36 & 1,46 & 2,24 \\
\hline & Jumlah (Total) & 6,0 & & & & 0,48 & & 4,32 \\
\hline \multirow[b]{2}{*}{5.} & Rubiaceae & & & & & & & \\
\hline & $\begin{array}{l}\text { Aidia densifolia (Benth.) } \\
\text { Masamune }\end{array}$ & 5,0 & 0,73 & 0,20 & 1,23 & 0,11 & 0,46 & 2,42 \\
\hline \multirow[t]{2}{*}{6.} & $\begin{array}{l}\text { Diplospora Malaccensis } \\
\text { Hook.f. }\end{array}$ & 2,0 & 0,29 & 0,08 & 0,49 & 0,04 & 0,16 & 0,94 \\
\hline & Jumlah (Total) & 7,0 & & & & 0,15 & & 3,36 \\
\hline 7. & Alangiaceae & & & & & & & \\
\hline 8. & $\begin{array}{l}\text { Alangium hirsutum Bloem. } \\
\text { Jumlah (Total) }\end{array}$ & $\begin{array}{l}1,0 \\
1,0\end{array}$ & 0,15 & 0,04 & 0,25 & $\begin{array}{l}0,05 \\
0,05\end{array}$ & 0,20 & $\begin{array}{l}0,59 \\
0,59\end{array}$ \\
\hline & Lauraceae & & & & & & & \\
\hline 9. & Alseodaphne sp. & 1,0 & 0,15 & 0,04 & 0,25 & 0,01 & 0,04 & 0,43 \\
\hline 10. & Cinnamomum sp. & 1,0 & 0,15 & 0,04 & 0,25 & 0,11 & 0,44 & 0,83 \\
\hline 11. & $\begin{array}{l}\text { Cryptocarya crassinervia } \\
\text { Miq. }\end{array}$ & 1,0 & 0,15 & 0,04 & 0,25 & 0,01 & 0,05 & 0,44 \\
\hline 12. & $\begin{array}{l}\text { Endiandra kingiana Gamble } \\
\text { Jumlah (Total) }\end{array}$ & $\begin{array}{l}5,0 \\
8,0\end{array}$ & 0,73 & 0,20 & 1,23 & $\begin{array}{l}0,34 \\
0,47\end{array}$ & 1,39 & $\begin{array}{l}3,35 \\
5,05\end{array}$ \\
\hline & Euphorbiaceae & & & & & & & \\
\hline 13. & Aporosa alia A.Schot & 12,0 & 1,75 & 0,32 & 1,97 & 0,13 & 0,53 & 4,24 \\
\hline 14. & $\begin{array}{l}\text { Aporosa lucida (Miq.) Airy } \\
\text { Shaw }\end{array}$ & 1,0 & 0,15 & 0,04 & 0,25 & 0,01 & 0,04 & 0,43 \\
\hline 15. & Aporosa nervosa Hook.f. & 5,0 & 0,73 & 0,16 & 0,98 & 0,11 & 0,44 & 2,15 \\
\hline 16. & Cleistanthus paxii Jabl. & 4,0 & 0,58 & 0,16 & 0,98 & 0,05 & 0,21 & 1,78 \\
\hline 17. & Cleistanthus sp. & 1,0 & 0,15 & 0,04 & 0,25 & 0,02 & 0,09 & 0,48 \\
\hline 18. & Cleistanthus sp.1 & 43,0 & 6,26 & 0,60 & 3,69 & 0,68 & 2,75 & 12,70 \\
\hline 19. & $\begin{array}{l}\text { Cleistanthus sumatranus } \\
\text { (Miq.) Muell. Arg. }\end{array}$ & 1,0 & 0,15 & 0,04 & 0,25 & 0,01 & 0,03 & 0,42 \\
\hline 20. & $\begin{array}{l}\text { Drypetes oblongifolia } \\
\text { (Bedd.) Airy Shaw }\end{array}$ & 3,0 & 0,44 & 0,12 & 0,74 & 0,05 & 0,20 & 1,37 \\
\hline 21. & Drypetes sp. & 1,0 & 0,15 & 0,04 & 0,25 & 0,02 & 0,07 & 0,46 \\
\hline 22. & $\begin{array}{l}\text { Endospermum diadenum } \\
\text { (Miq.) Airy Shaw }\end{array}$ & 5,0 & 0,73 & 0,20 & 1,23 & 0,12 & 0,48 & 2,44 \\
\hline 23. & $\begin{array}{l}\text { Glochidion obscurum (Roxb. } \\
\text { Ex Willd.) Blume }\end{array}$ & 5,0 & 0,73 & 0,12 & 0,74 & 0,11 & 0,44 & 1,91 \\
\hline 24. & $\begin{array}{l}\text { Macaranga bancana (Miq.) } \\
\text { Muell.Arg. }\end{array}$ & 11,0 & 1,60 & 0,28 & 1,72 & 0,13 & 0,54 & 3,86 \\
\hline 25. & $\begin{array}{l}\text { Macaranga conifera (Zoll.) } \\
\text { Moel. Arg. }\end{array}$ & 10,0 & 1,46 & 0,24 & 1,47 & 0,13 & 0,55 & 3,48 \\
\hline 26. & $\begin{array}{l}\text { Macaranga gigantea } \\
\text { (Reichb.f. \& Zoll.) } \\
\text { Moell.Arg. }\end{array}$ & 6,0 & 0,87 & 0,24 & 1,47 & 0,15 & 0,59 & 2,94 \\
\hline 27. & $\begin{array}{l}\text { Macaranga hosei King ex } \\
\text { Hook.f. }\end{array}$ & 137,0 & 19,94 & 0,76 & 4,67 & 2,46 & 10,05 & 34,66 \\
\hline 28. & $\begin{array}{l}\text { Macaranga hypoleuca } \\
\text { (Reichb.f. \& Zoll.) } \\
\text { Maoel.Arg. }\end{array}$ & 3,0 & 0,44 & 0,08 & 0,49 & 0,04 & 0,17 & 1,10 \\
\hline 29. & Macaranga polyadenia & 6,0 & 0,87 & 0,12 & 0,74 & 0,18 & 0,74 & 2,35 \\
\hline 30. & $\begin{array}{l}\text { Mallotus mollissimus } \\
\text { (Geiseler) Airy Shaw }\end{array}$ & 5,0 & 0,73 & 0,12 & 0,74 & 0,09 & 0,35 & 1,82 \\
\hline
\end{tabular}


Lampiran (Appendix) 1. Lanjutan (Continued)

\begin{tabular}{|c|c|c|c|c|c|c|c|c|}
\hline No. & $\begin{array}{c}\text { Famili dan jenis } \\
\text { (Family and species) }\end{array}$ & $\begin{array}{c}\mathrm{K} \\
(D)\end{array}$ & $\begin{array}{c}\mathrm{Kr} \\
(R D)\end{array}$ & $\mathrm{F}$ & $\begin{array}{c}\mathrm{FR} \\
(R F)\end{array}$ & $\begin{array}{c}\mathrm{D} \\
(B A)\end{array}$ & $\begin{array}{c}\mathrm{DR} \\
(R B A)\end{array}$ & $\begin{array}{l}\text { INP (IVI) } \\
(\%)\end{array}$ \\
\hline 31. & $\begin{array}{l}\text { Omalanthus sp. } \\
\text { Jumlah (Total) }\end{array}$ & $\begin{array}{l}2,0 \\
261\end{array}$ & 0,29 & 0,08 & 0,49 & $\begin{array}{l}0,09 \\
4,58\end{array}$ & 0,36 & $\begin{array}{c}1,14 \\
79,73\end{array}$ \\
\hline $\begin{array}{l}32 . \\
33 .\end{array}$ & $\begin{array}{l}\text { Leguminosae } \\
\text { Archidendron sp. } \\
\text { Parkia speciosa Hassk. } \\
\text { Jumlah (Total) }\end{array}$ & $\begin{array}{l}8,0 \\
1,0 \\
9,0\end{array}$ & $\begin{array}{l}1,16 \\
0,15\end{array}$ & $\begin{array}{l}0,28 \\
0,04\end{array}$ & $\begin{array}{l}1,72 \\
0,25\end{array}$ & $\begin{array}{l}0,16 \\
0,15 \\
0,31 \\
\end{array}$ & $\begin{array}{l}0,64 \\
0,63\end{array}$ & $\begin{array}{l}3,52 \\
1,02 \\
4,54\end{array}$ \\
\hline 34. & $\begin{array}{l}\text { Moraceae } \\
\text { Artocarpus lanceifolius Roxb. } \\
\text { Jumlah (Total) }\end{array}$ & $\begin{array}{l}1,0 \\
1,0\end{array}$ & 0,15 & 0,04 & 0,25 & $\begin{array}{l}0,04 \\
0,04\end{array}$ & 0,16 & $\begin{array}{l}0,55 \\
0,55\end{array}$ \\
\hline 35. & $\begin{array}{l}\text { Lecythidaceae } \\
\text { Barringtonia sp. } \\
\text { Jumlah (Total) }\end{array}$ & $\begin{array}{l}1,0 \\
1,0\end{array}$ & 0,15 & 0,04 & 0,25 & $\begin{array}{l}0,01 \\
0,01\end{array}$ & 0,04 & $\begin{array}{l}0,43 \\
0,43\end{array}$ \\
\hline $\begin{array}{l}36 . \\
37 . \\
38 . \\
39 .\end{array}$ & $\begin{array}{l}\text { Anacardiaceae } \\
\text { Boea macropyhlla Griff. } \\
\text { cf. Spondias } \\
\text { Mangifera foetida Lour. } \\
\text { Melanochylla sp. } \\
\text { Jumlah (Total) }\end{array}$ & $\begin{array}{l}2,0 \\
1,0 \\
1,0 \\
1,0 \\
5,0\end{array}$ & $\begin{array}{l}0,29 \\
0,15 \\
0,15 \\
0,15\end{array}$ & $\begin{array}{l}0,08 \\
0,04 \\
0,04 \\
0,04\end{array}$ & $\begin{array}{l}0,49 \\
0,25 \\
0,25 \\
0,25\end{array}$ & $\begin{array}{l}0,02 \\
0,07 \\
0,04 \\
0,01 \\
0,14\end{array}$ & $\begin{array}{l}0,08 \\
0,29 \\
0,18 \\
0,05\end{array}$ & $\begin{array}{l}0,86 \\
0,68 \\
0,57 \\
0,44 \\
2,55\end{array}$ \\
\hline 40. & $\begin{array}{l}\text { Burseraceae } \\
\text { Canarium denticulatum } \\
\text { Blume }\end{array}$ & 4,0 & 0,58 & 0,16 & 0,98 & 0,05 & 0,21 & 1,78 \\
\hline 41. & $\begin{array}{l}\text { Dacryodes incurvata H.J. } \\
\text { Lamk. }\end{array}$ & 1,0 & 0,15 & 0,04 & 0,25 & 0,04 & 0,17 & 0,56 \\
\hline 42. & $\begin{array}{l}\text { Dacryodes rugosa (Blume) } \\
\text { H.J.Lam }\end{array}$ & 1,0 & 0,15 & 0,04 & 0,25 & 0,04 & 0,17 & 0,56 \\
\hline $\begin{array}{l}43 . \\
44 . \\
45 .\end{array}$ & $\begin{array}{l}\text { Santiria apiculata A.W.Benn. } \\
\text { Santiria oblongifolia Blume } \\
\text { Santiria tomentosa Blume } \\
\text { Jumlah (Total) }\end{array}$ & $\begin{array}{l}1,0 \\
1,0 \\
4,0 \\
12\end{array}$ & $\begin{array}{l}0,15 \\
0,15 \\
0,58\end{array}$ & $\begin{array}{l}0,04 \\
0,04 \\
0,16\end{array}$ & $\begin{array}{l}0,25 \\
0,25 \\
0,98\end{array}$ & $\begin{array}{l}0,04 \\
0,11 \\
0,33 \\
0,61\end{array}$ & $\begin{array}{l}0,18 \\
0,43 \\
1,34\end{array}$ & $\begin{array}{l}0,57 \\
0,82 \\
2,90 \\
7,19\end{array}$ \\
\hline 46. & $\begin{array}{l}\text { Crypteroniaceae } \\
\text { Crypteronia griffithii C.B. } \\
\text { Clarke } \\
\text { Crypteronia sp. } \\
\text { Jumlah (Total) }\end{array}$ & $\begin{array}{l}1,0 \\
3,0\end{array}$ & 0,29 & 0,08 & 0,49 & $\begin{array}{l}0,04 \\
0,07 \\
0,11 \\
\end{array}$ & $\begin{array}{l}0,15 \\
0,27\end{array}$ & $\begin{array}{c}0,94 \\
0,66 \\
1,6 \\
\end{array}$ \\
\hline $\begin{array}{l}49 . \\
50 . \\
51 . \\
52 . \\
53 .\end{array}$ & $\begin{array}{l}\text { Annonaceae } \\
\text { Cyathocalyx sumatrana } \\
\text { Scheff. } \\
\text { Mezzettia parvifolia Becc. } \\
\text { Polyalthia sp. } \\
\text { Orophea trigyna Miq. } \\
\text { Xylopia ferruginea Baill. } \\
\text { Xylopia sp. } \\
\text { Jumlah (Total) } \\
\end{array}$ & $\begin{array}{l}1,0 \\
1,0 \\
7,0 \\
1,0 \\
2,0 \\
22\end{array}$ & $\begin{array}{l}0,15 \\
0,15 \\
1,02 \\
0,15 \\
0,29\end{array}$ & $\begin{array}{l}0,04 \\
0,04 \\
0,24 \\
0,04 \\
0,08\end{array}$ & $\begin{array}{l}0,25 \\
0,25 \\
1,47 \\
0,25 \\
0,49\end{array}$ & $\begin{array}{l}0,13 \\
0,01 \\
0,01 \\
0,16 \\
0,01 \\
0,03 \\
0,35\end{array}$ & $\begin{array}{l}0,52 \\
0,03 \\
0,05 \\
0,66 \\
0,05 \\
0,12\end{array}$ & $\begin{array}{c}3,94 \\
0,42 \\
0,44 \\
3,15 \\
0,45 \\
0,90 \\
9,3 \\
\end{array}$ \\
\hline 54. & $\begin{array}{l}\text { Ebenaceae } \\
\text { Diospyros buxyfolia (Blume) } \\
\text { Hiern }\end{array}$ & 13,0 & 1,89 & 0,28 & 1,72 & 0,48 & 1,96 & 5,57 \\
\hline $\begin{array}{l}55 . \\
56 .\end{array}$ & $\begin{array}{l}\text { Diospyros pilosanthera } \\
\text { Diospyros polyalthioides } \\
\text { Hiern }\end{array}$ & $\begin{array}{l}1,0 \\
8,0\end{array}$ & $\begin{array}{l}0,15 \\
1,16\end{array}$ & $\begin{array}{l}0,04 \\
0,24\end{array}$ & $\begin{array}{l}0,25 \\
1,47\end{array}$ & $\begin{array}{l}0,01 \\
0,12\end{array}$ & $\begin{array}{l}0,04 \\
0,48\end{array}$ & $\begin{array}{l}0,43 \\
3,11\end{array}$ \\
\hline 57. & $\begin{array}{l}\text { Diospyros sp. } \\
\text { Jumlah (Total) }\end{array}$ & $\begin{array}{c}12,0 \\
34\end{array}$ & 1,75 & 0,28 & 1,72 & $\begin{array}{l}0,23 \\
0,84\end{array}$ & 0,94 & $\begin{array}{c}4,41 \\
13,52\end{array}$ \\
\hline $\begin{array}{l}58 . \\
59 . \\
60 .\end{array}$ & $\begin{array}{l}\text { Dipterocarpaceae } \\
\text { Dipterocarpus sp. } \\
\text { Shorea agamii P.S.Ashton } \\
\text { Shorea angustifolia } \\
\text { P.S.Ashton }\end{array}$ & $\begin{array}{l}3,0 \\
3,0 \\
7,0\end{array}$ & $\begin{array}{l}0,44 \\
0,44 \\
1,02\end{array}$ & $\begin{array}{l}0,12 \\
0,08 \\
0,28\end{array}$ & $\begin{array}{l}0,74 \\
0,49 \\
1,72\end{array}$ & $\begin{array}{l}0,84 \\
0,36 \\
0,13\end{array}$ & $\begin{array}{l}3,42 \\
1,47 \\
0,52\end{array}$ & $\begin{array}{l}4,59 \\
2,40 \\
3,26\end{array}$ \\
\hline
\end{tabular}


Lampiran (Appendix) 1. Lanjutan (Continued)

\begin{tabular}{|c|c|c|c|c|c|c|c|c|}
\hline No. & $\begin{array}{c}\text { Famili dan jenis } \\
\text { (Family and species) }\end{array}$ & $\begin{array}{c}\mathrm{K} \\
(D) \\
\end{array}$ & $\begin{array}{c}\mathrm{Kr} \\
(R D)\end{array}$ & $\mathrm{F}$ & $\begin{array}{c}\text { FR } \\
(R F)\end{array}$ & $\begin{array}{c}\mathrm{D} \\
(B A) \\
\end{array}$ & $\begin{array}{c}\mathrm{DR} \\
(R B A)\end{array}$ & $\begin{array}{l}\text { INP (IVI) } \\
(\%)\end{array}$ \\
\hline 61. & $\begin{array}{l}\text { Shorea inappendiculata } \\
\text { Burck }\end{array}$ & 6,0 & 0,87 & 0,24 & 1,47 & 2,34 & 9,56 & 11,91 \\
\hline 62. & $\begin{array}{l}\text { Shorea multiflora (Burk) } \\
\text { Symington }\end{array}$ & 30,0 & 4,37 & 0,56 & 3,44 & 1,10 & 4,48 & 12,29 \\
\hline 63. & Shorea sp.1 & 39,0 & 5,68 & 0,72 & 4,42 & 2,40 & 9,78 & 19,88 \\
\hline 64. & Shorea sp.2 & 2,0 & 0,29 & 0,08 & 0,49 & 0,02 & 0,07 & 0,85 \\
\hline 65. & $\begin{array}{l}\text { Vatica sp. } \\
\text { Jumlah (Total) }\end{array}$ & $\begin{array}{l}6,0 \\
96\end{array}$ & 0,87 & 0,20 & 1,23 & $\begin{array}{c}0,11 \\
7,3\end{array}$ & 0,46 & $\begin{array}{c}2,56 \\
57,74\end{array}$ \\
\hline 66. & $\begin{array}{l}\text { Bombacaceae } \\
\text { Durio excelsus Griff. } \\
\text { Jumlah (Total) } \\
\end{array}$ & $\begin{array}{l}17,0 \\
17,0 \\
\end{array}$ & 2,47 & 0,48 & 2,95 & $\begin{array}{c}1,00 \\
7,3 \\
\end{array}$ & 4,06 & $\begin{array}{l}9,48 \\
9,48 \\
\end{array}$ \\
\hline 67. & $\begin{array}{l}\text { Elaeocarpaceae } \\
\text { Elaeocarpus stipularis Blume } \\
\text { Jumlah (Total) }\end{array}$ & $\begin{array}{l}2,0 \\
2,0\end{array}$ & 0,29 & 0,08 & 0,49 & $\begin{array}{l}0,07 \\
0,07 \\
\end{array}$ & 0,27 & $\begin{array}{l}1,06 \\
1,06\end{array}$ \\
\hline $\begin{array}{l}68 . \\
69 .\end{array}$ & $\begin{array}{l}\text { Simaroubaceae } \\
\text { Eurycoma longifolia Jack } \\
\text { Irvingia malayana Oliv. } \\
\text { Jumlah (Total) } \\
\end{array}$ & $\begin{array}{l}3,0 \\
2,0 \\
5,0 \\
\end{array}$ & $\begin{array}{l}0,44 \\
0,29\end{array}$ & $\begin{array}{l}0,12 \\
0,08\end{array}$ & $\begin{array}{l}0,74 \\
0,49\end{array}$ & $\begin{array}{l}0,05 \\
0,04 \\
0,09 \\
\end{array}$ & $\begin{array}{l}0,19 \\
0,16\end{array}$ & $\begin{array}{l}1,36 \\
0,94 \\
2,30 \\
\end{array}$ \\
\hline $\begin{array}{l}70 . \\
71 . \\
72 . \\
73 . \\
74 .\end{array}$ & $\begin{array}{l}\text { Guttiferae } \\
\text { Garcinia beccariana } \\
\text { Garcinia sp. } \\
\text { Garcinia sp.1 } \\
\text { Garcinia sp.2 } \\
\text { Messua sp. } \\
\text { Jumlah (Total) }\end{array}$ & $\begin{array}{c}1,0 \\
3,0 \\
8,0 \\
4,0 \\
11,0 \\
27 \\
\end{array}$ & $\begin{array}{l}0,15 \\
0,44 \\
1,16 \\
0,58 \\
1,60\end{array}$ & $\begin{array}{l}0,04 \\
0,12 \\
0,24 \\
0,12 \\
0,32\end{array}$ & $\begin{array}{l}0,25 \\
0,74 \\
1,47 \\
0,74 \\
1,97\end{array}$ & $\begin{array}{l}0,01 \\
0,21 \\
0,16 \\
0,10 \\
0,38 \\
0,86 \\
\end{array}$ & $\begin{array}{l}0,04 \\
0,85 \\
0,67 \\
0,40 \\
1,54\end{array}$ & $\begin{array}{c}0,43 \\
2,03 \\
3,30 \\
1,71 \\
5,10 \\
12,57 \\
\end{array}$ \\
\hline 75. & $\begin{array}{l}\text { Ulmaceae } \\
\text { Gironniera nervosa Planch. } \\
\text { Jumlah (Total) }\end{array}$ & $\begin{array}{l}2,0 \\
2,0\end{array}$ & 0,29 & 0,08 & 0,49 & $\begin{array}{l}0,11 \\
0,11 \\
\end{array}$ & 0,44 & $\begin{array}{l}1,23 \\
1,23\end{array}$ \\
\hline $\begin{array}{l}76 . \\
77 .\end{array}$ & $\begin{array}{l}\text { Thymelaeaceae } \\
\text { Gonystylus affinis Radlk } \\
\text { Gonystylus velutinus Airy } \\
\text { Show } \\
\text { Jumlah (Total) }\end{array}$ & $\begin{array}{l}4,0 \\
1,0 \\
5,0\end{array}$ & $\begin{array}{l}0,58 \\
0,15\end{array}$ & $\begin{array}{l}0,12 \\
0,04\end{array}$ & $\begin{array}{l}0,74 \\
0,25\end{array}$ & $\begin{array}{l}0,20 \\
0,02 \\
0,22\end{array}$ & $\begin{array}{l}0,81 \\
0,10\end{array}$ & $\begin{array}{l}2,13 \\
0,49 \\
2,62\end{array}$ \\
\hline $\begin{array}{l}78 . \\
79 .\end{array}$ & $\begin{array}{l}\text { Proteaceae } \\
\text { Heliciopsis sp. } \\
\text { Heliciopsis velutina (Prain) } \\
\text { Sleumer } \\
\text { Jumlah (Total) }\end{array}$ & $\begin{array}{l}1,0 \\
1,0 \\
2,0\end{array}$ & $\begin{array}{l}0,15 \\
0,15\end{array}$ & $\begin{array}{l}0,04 \\
0,04\end{array}$ & $\begin{array}{l}0,25 \\
0,25\end{array}$ & $\begin{array}{l}0,02 \\
0,02 \\
0,04\end{array}$ & $\begin{array}{l}0,08 \\
0,09\end{array}$ & $\begin{array}{l}0,47 \\
0,48 \\
0,95\end{array}$ \\
\hline 80. & $\begin{array}{l}\text { Flacourtiaceae } \\
\text { Hydnocarpus elmerii } \\
\text { Jumlah (Total) }\end{array}$ & $\begin{array}{l}3,0 \\
3,0\end{array}$ & 0,44 & 0,12 & 0,74 & $\begin{array}{l}0,19 \\
0,19\end{array}$ & 0,77 & $\begin{array}{l}1,95 \\
1,95\end{array}$ \\
\hline $\begin{array}{l}81 . \\
82 .\end{array}$ & $\begin{array}{l}\text { Myristicaceae } \\
\text { Knema glauca (Blume) Warb. } \\
\text { Knema pallens W.J.J.O. de } \\
\text { Wilde }\end{array}$ & $\begin{array}{c}1,0 \\
13,0\end{array}$ & $\begin{array}{l}0,15 \\
1,89\end{array}$ & $\begin{array}{l}0,04 \\
0,28\end{array}$ & $\begin{array}{l}0,25 \\
1,72\end{array}$ & $\begin{array}{l}0,02 \\
0,19\end{array}$ & $\begin{array}{l}0,10 \\
0,77\end{array}$ & $\begin{array}{l}0,49 \\
4,38\end{array}$ \\
\hline $\begin{array}{l}83 . \\
84 . \\
85 . \\
86 .\end{array}$ & $\begin{array}{l}\text { Knema percoriacea J.Sinclair } \\
\text { Myristica cinnamomea King } \\
\text { Myristica inners Blume } \\
\text { Myristica villosa Warb. } \\
\text { Jumlah (Total) }\end{array}$ & $\begin{array}{l}1,0 \\
2,0 \\
5,0 \\
1,0 \\
23\end{array}$ & $\begin{array}{l}0,15 \\
0,29 \\
0,73 \\
0,15\end{array}$ & $\begin{array}{l}0,04 \\
0,08 \\
0,20 \\
0,04\end{array}$ & $\begin{array}{l}0,25 \\
0,49 \\
1,23 \\
0,25\end{array}$ & $\begin{array}{l}0,39 \\
0,07 \\
0,10 \\
0,06 \\
0,83\end{array}$ & $\begin{array}{l}1,57 \\
0,29 \\
0,43 \\
0,23\end{array}$ & $\begin{array}{c}1,96 \\
1,08 \\
2,38 \\
0,62 \\
10,91 \\
\end{array}$ \\
\hline $\begin{array}{l}87 . \\
88 . \\
89 . \\
90 .\end{array}$ & $\begin{array}{l}\text { Fagaceae } \\
\text { Lithocarpus sp. } \\
\text { Lithocarpus sp.1 } \\
\text { Lithocarpus sp.2 } \\
\text { Lithocarpus sp.3 } \\
\text { Jumlah (Total) }\end{array}$ & $\begin{array}{l}1,0 \\
8,0 \\
2,0 \\
1,0 \\
12\end{array}$ & $\begin{array}{l}0,15 \\
1,16 \\
0,29 \\
0,15\end{array}$ & $\begin{array}{l}0,04 \\
0,28 \\
0,08 \\
0,04\end{array}$ & $\begin{array}{l}0,25 \\
1,72 \\
0,49 \\
0,25\end{array}$ & $\begin{array}{l}0,01 \\
0,38 \\
0,08 \\
0,01 \\
0,48\end{array}$ & $\begin{array}{l}0,06 \\
1,56 \\
0,32 \\
0,04\end{array}$ & $\begin{array}{l}0,45 \\
4,44 \\
1,10 \\
0,43 \\
6,42\end{array}$ \\
\hline
\end{tabular}


Lampiran (Appendix) 1. Lanjutan (Continued)

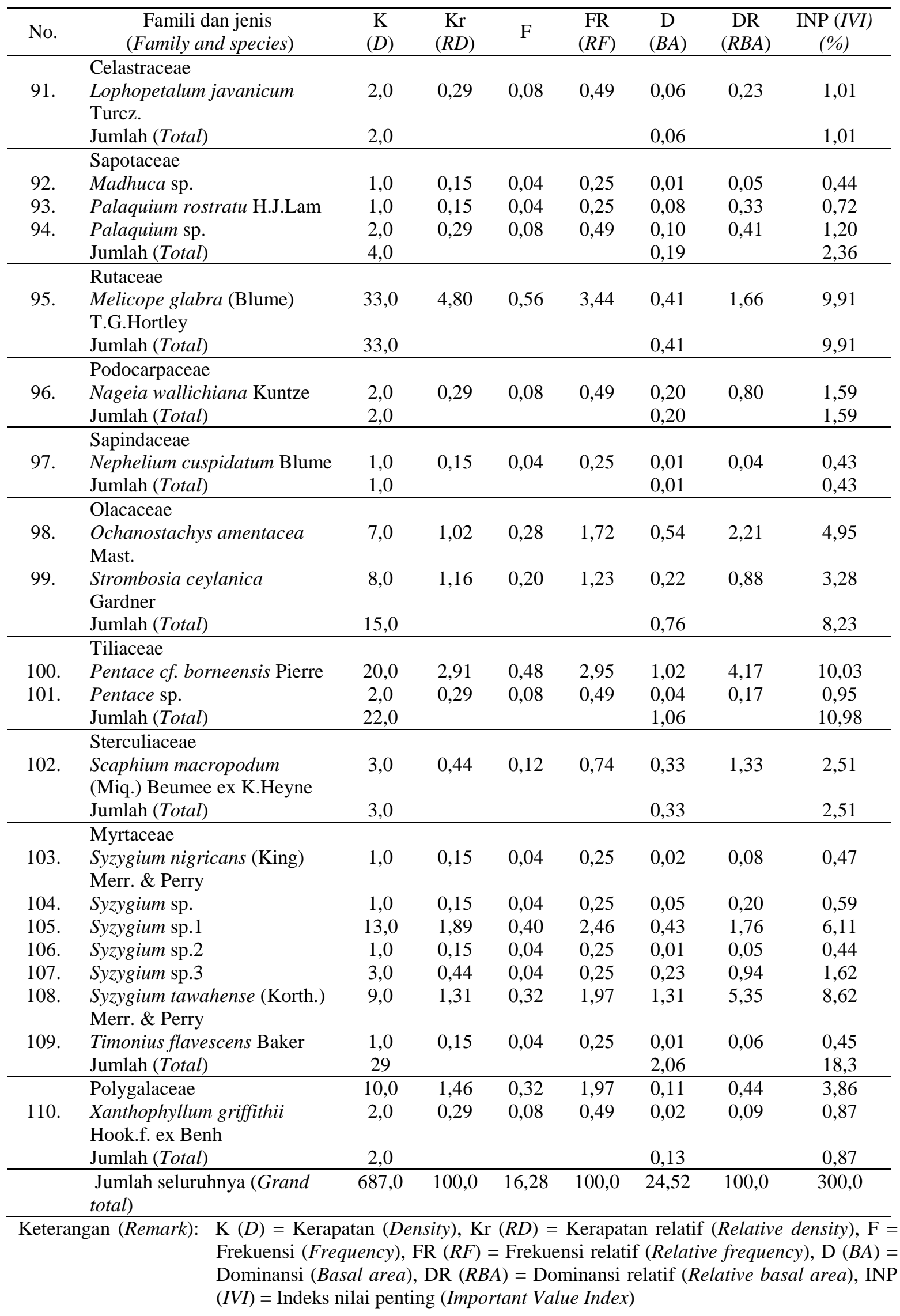


Lampiran (Appendix) 2. Jumlah suku dan jumlah pohon dalam plot satu ha di lokasi penelitian (Number of family and trees in a 1-ha plot at the study site)

\begin{tabular}{|c|c|c|c|}
\hline No. & Famili (Family) & $\begin{array}{c}\text { Jumlah jenis (Number of species) } \\
\text { (jenis) }\end{array}$ & $\begin{array}{l}\text { Jumlah pohon (Number of trees) } \\
\text { (individu) }\end{array}$ \\
\hline 1 & Alangiaceae & 1 & 1 \\
\hline 2 & Anacardiaceae & 4 & 5 \\
\hline 3 & Annonaceae & 6 & 22 \\
\hline 4 & Bombacaceae & 1 & 17 \\
\hline 5 & Burseraceae & 6 & 12 \\
\hline 6 & Celastraceae & 1 & 2 \\
\hline 7 & Crypteroniaceae & 2 & 3 \\
\hline 8 & Dipterocarpaceae & 8 & 96 \\
\hline 9 & Ebenaceae & 4 & 34 \\
\hline 10 & Elaeocarpaceae & 1 & 2 \\
\hline 11 & Euphorbiaceae & 19 & 261 \\
\hline 12 & Fagaceae & 4 & 12 \\
\hline 13 & Flacourtiaceae & 1 & 3 \\
\hline 14 & Guttiferae & 5 & 27 \\
\hline 15 & Lauraceae & 4 & 8 \\
\hline 16 & Lecythidaceae & 1 & 1 \\
\hline 17 & Leguminosae & 2 & 9 \\
\hline 18 & Meliaceae & 4 & 6 \\
\hline 19 & Moraceae & 1 & 1 \\
\hline 20 & Myristicaceae & 6 & 23 \\
\hline 21 & Myrtaceae & 7 & 29 \\
\hline 22 & Olacaceae & 2 & 15 \\
\hline 23 & Podocarpaceae & 1 & 2 \\
\hline 24 & Polygalaceae & 2 & 12 \\
\hline 25 & Proteaceae & 2 & 2 \\
\hline 26 & Rubiaceae & 2 & 7 \\
\hline 27 & Rutaceae & 1 & 33 \\
\hline 28 & Sapindaceae & 1 & 1 \\
\hline 29 & Sapotaceae & 3 & 4 \\
\hline 30 & Simaroubaceae & 2 & 5 \\
\hline 31 & Sterculiaceae & 1 & 3 \\
\hline 32 & Thymelaeaceae & 2 & 5 \\
\hline 33 & Tiliaceae & 2 & 22 \\
\hline \multirow[t]{2}{*}{34} & Ulmaceae & 1 & 2 \\
\hline & Jumlah (Total) & 110 & 687 \\
\hline
\end{tabular}

